\title{
Sandy Bolan*
}

Lutando contra os impactos do colonialismo, Lee Maracle, escritora de origem Salish e Cree, tribos da costa oeste do Canadá, acumula trabalhos de ficção e não-ficção que têm por objetivo um contato direto com seu próprio povo, chamando-o para a ação.

Nascida em 1950 em Vancouver, Canadá, a escritora cria obras que rompem com os estereótipos do aborígine e procuram mostrar o índio real, com sua identidade autêntica, afirmando valores tradicionais e buscando a retomada da cultura original do nativo canadense. Além da literatura, Maracle atua em movimentos pró-aborígines, lutando pelo reconhecimento do nativo e defendendo fortemente os direitos feministas.

Seu romance mais recente, Daughters are Forever (Vancouver, Polestar: 2002), conta a história de Marilyn, uma assistente social de origem Salish, que passa por um desequilíbrio que gera um processo de auto-conhecimento. A personagem é levada a se reconectar com seu passado e a cultura de seu povo, enfrentando um ritual de cura, para se restabelecer como mãe. Em páginas de imenso valor poético, a autora resgata as características da tradição oral e tece a trajetória de apenas uma mulher, mas que pode representar todo o povo aborígine.

Já que a ficção aborígine não se conforma aos padrões da literatura euroamericana, para entrarmos neste mundo precisamos estar atentos para a mudança de posicionamento do índio, agora no centro do romance, e às diferentes características e significações simbólicas de seus elementos. Assim, a oportunidade de uma conversa ${ }^{\dagger}$ com a própria autora de Daughters nos permitiu buscar informações sobre sua obra. Suas respostas mostram quão profunda é sua produção e quanto mais podemos conhecer sobre a cultura aborígine através da obra de escritores de origem nativa.

* Sandy Bolan é graduada em Letras Português/Inglês - Bacharelado em Literatura, na Universidade Federal do Paraná.

${ }^{\dagger}$ Entrevista realizada em inglês através de correio eletrônico, entre abril e novembro de 2007. Tradução minha. 


\section{Você teve uma intenção ideológica em foco quando escreveu Daughters are Forever?}

Lee Maracle: Eu tive uma intenção definida, não tenho certeza se foi simplesmente ideológica. Primeiro: e se for verdade que o Vento Oeste foi o pai dos gêmeos? Segundo, e se for verdade que os mortos que não são enterrados devidamente ainda andam através dos ventos nos chamando? Terceiro, e se eu contei a história baseada em cerimônias de Reconciliação Familiar e o descobrimento de "respiração" em uma mulher que era abusiva? E se eu contei a partir das "perspectivas e práticas de cura de meu próprio povo"? E se as personagens centrais para nossa modalidade de cura desempenharam um papel na história: Bluejay, Mulher Selvagem, Vento Oeste, Corvo, Cedro, etc. Eu, de fato, tenho uma percepção do impacto (colonial) no bem-estar (modalidades de cura) e a significação das histórias e eu uso todas as opções acima para desenrolar a história da origem ao presente.

Eu sei que sua filha Columpa é atriz e uma das filhas de Marilyn também é atriz. Você usou de sua experiência com suas próprias filhas para criar o relacionamento entre Lindy, Cat e Marilyn? O romance é totalmente ficcional?

Lee Maracle: Sim, nós usamos. Nós conversamos muito sobre isso juntas, então, sim, nós criamos as experiências ficcionais para mostrar a jornada de transformação em nossas vidas reais.

Como você sente que a literatura, e especialmente seu próprio trabalho, tem impactado a comunidade ao seu redor, no Canadá, e no resto do mundo?

Lee Maracle: Quando as pessoas lêem meu trabalho e conversam comigo, geralmente me dizem que as impactou de uma maneira profunda, ou que elas não gostaram NEM UM POUCO. Parece que não há nenhum sentimento neutro sobre ele. Há uma série de ensaios sobre meu trabalho. Do meu ponto de vista, eu acredito que as histórias são aquelas que eu acho que precisam ser escritas. Eu construo meu trabalho com cuidado e eles são minha melhor expressão. Não sei de que outra forma eu poderia responder isto. Certamente, canadenses e outros têm passado por uma mudança de sentimentos, não apenas por causa de meu trabalho, mas pelo trabalho de outros. Eu também acredito que temos escritores aborígines hoje porque alguns de nós abriram o caminho: Armstrong, Culleton, Campbell e eu.

Tomei conhecimento de que, além de sua filha, seu filho, seu avô e você mesma todos têm experiência como atores. Você vê proximidade entre o trabalho de atores e de escritores?

Lee Maracle: Aí está uma pergunta que me deixa perdida. Eu acho que atuar tem a ver com o corpo e eu realmente tento buscar fundo de dentro do meu corpo enquanto eu escrevo, mas nunca vi as duas coisas como sendo lá muito ligadas. Vou pensar um pouco mais.

De certa forma, Daughters, apesar de que nada no enredo tenha realmente acontecido e eu não seja nenhum tipo de assistente social, eu o escrevi depois de passar por reconciliação familiar e cura com minhas filhas. Então, é ficção que me é cara. Eu acho que até um certo ponto eu me fundei na natureza tortuosa de nosso relacionamento passado e as características de minhas filhas para desenvolver a história. Por outro lado, não é autobiográfica. Meu pai, por exemplo, está bem vivo aos 86 anos. É minha mãe que é falecida e eu tinha 40 anos quando isso aconteceu. Meu pai bebia um pouco, sim, mas eu não diria que ele era nada como o Eddy. Eu não consigo imaginar meu pai correndo na frente de um caminhão para fugir das vozes do vento. Eu não posso me imaginar como uma assistente social. E quando meus filhos eram ainda adolescentes eu já havia passado por um bocado de terapia, então todo o problema de "desligar" já era parte de um entendimento da psicologia de base ocidental, terapia de base indígena e resposta a traumas. Está ligado a mim e minhas filhas me ajudaram na produção. Eu não acho que isso o torne autobiográfico. 
Questões autobiográficas à parte, a leitura deste romance nos faz lembrar a importância de um resgate cultural do passado e do respeito pelas diferenças. Este movimento póscolonial coloca o índio no centro do romance, como mencionado, conquistando um espaço e atenção que nunca antes obteve, chamando a atenção da sociedade para a riqueza de suas tradições indígenas.

Aqui mesmo no Brasil vários escritores de nossas muitas tribos e etnias têm seguido o exemplo de escritores de outras nações, como o de Maracle, do Canadá, e buscado uma abordagem "intelectual” à população que os rodeia, fomentando respeito a partir de conhecimento. Em um país em que os índios são tratados como um problema a ser ignorado, e não como pessoas, podemos perceber como a luta destes povos tem se diversificado e utilizado das próprias ferramentas do colonizador, como a literatura, para isto.

Autores como Daniel Munduruku, Graça Graúna, Eliane Potiguara, e Olívio Jekupê, para citar alguns, têm se organizado em encontros para escritores indígenas e grupos de estudo que trocam informações e experiências, buscando um melhor desempenho na produção literária. Até mesmo através da participação em encontros internacionais, escritores aborígines de todo o mundo vêm se unindo para que sua atuação em movimentos sociais e literários seja vista com seriedade, e para obter juntos o crescimento e amadurecimento destes profissionais.

De um universo de encantos inéditos e novas facetas que não se conformam aos padrões da mainstream literária, surge uma produção que é arte em movimento. A literatura de autoria aborígine nos apresenta as diferenças. Diferenças que nos fazem apreciar a diversidade do planeta. 